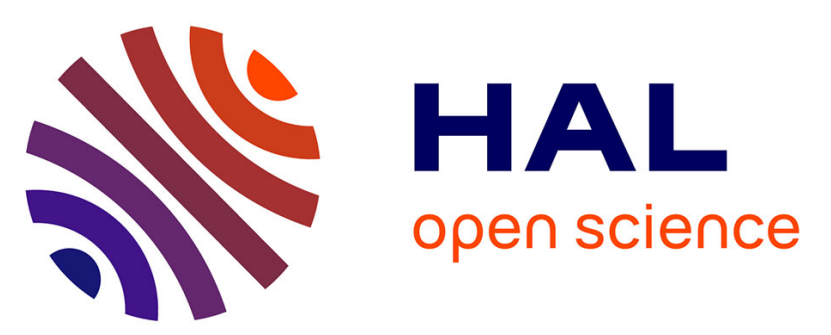

\title{
Optical microalgal biosensors for aqueous contaminants using organically doped silica as cellular hosts
}

Nada Ben Ahmed, Sylvie Masse, Guillaume Laurent, Jean-Yves Piquemal, Claude Yéprémian, Roberta Brayner, T. Coradin

\section{To cite this version:}

Nada Ben Ahmed, Sylvie Masse, Guillaume Laurent, Jean-Yves Piquemal, Claude Yéprémian, et al.. Optical microalgal biosensors for aqueous contaminants using organically doped silica as cellular hosts. Analytical and Bioanalytical Chemistry, 2018, 410 (4), pp.1205-1216. 10.1007/s00216-017-0405-8 . hal-01533631

\section{HAL Id: hal-01533631 \\ https: / hal.sorbonne-universite.fr/hal-01533631}

Submitted on 6 Jun 2017

HAL is a multi-disciplinary open access archive for the deposit and dissemination of scientific research documents, whether they are published or not. The documents may come from teaching and research institutions in France or abroad, or from public or private research centers.
L'archive ouverte pluridisciplinaire HAL, est destinée au dépôt et à la diffusion de documents scientifiques de niveau recherche, publiés ou non, émanant des établissements d'enseignement et de recherche français ou étrangers, des laboratoires publics ou privés.

\section{(1)(1) $\$(0)$}

Distributed under a Creative Commons Attribution - NonCommercial - ShareAlikel 4.0 


\section{Optical microalgal biosensors for aqueous contaminants using organically doped silica as cellular hosts}

Nada Ben Ahmed, ${ }^{\text {a,b }}$ Sylvie Masse, ${ }^{a}$ Guillaume Laurent, ${ }^{a}$ Jean-Yves Piquemal, ${ }^{b}$ Claude Yéprémian, ${ }^{c}$ Roberta Brayner, ${ }^{b, *}$ Thibaud Coradin a,*

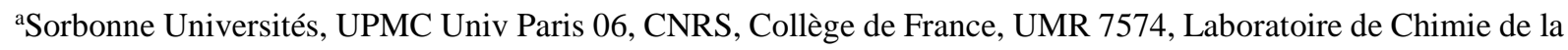
Matière Condensée de Paris, 4 place Jussieu, F-75005 Paris, France

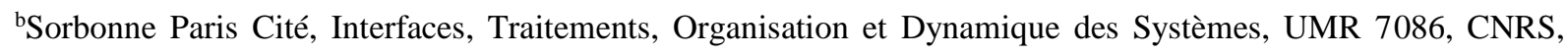
Paris-Diderot University, 15 rue Jean de Baïf, F-75013 Paris, France

'Département RDDM, UMR 7245, Unité MCAM, Muséum National d'Histoire Naturelle, 57 rue Cuvier, F-75005 Paris, France

*corresponding authors : T.C : tel : 33-1-44274018 ; E-mail : thibaud.coradin@ upmc.fr R.B. : tel : 33-1- 57278764; E-mail : roberta.brayner@univ-paris-diderot.fr 


\begin{abstract}
Optical biosensors for the detection of toxic species in aqueous media were developed via the encapsulation of microalgae in sol-gel matrices. In a first step, the effect of cadmium(II), lead (II) and anthracene on the chlorophyll a fluorescence intensity of Anabaena flos-aquae, Chorella vulgaris and Euglena gracilis microalgae in suspension was studied. Complementary ATP-metry measurements demonstrated a direct relationship between optical response and pollutant toxicity, in a cell- and dose-dependent manner. In a second step, microalgae were successfully encapsulated in silicate/colloidal silica nanocomposite matrices. However a complete loss of cell response to pollutant addition was observed, despite the preservation of cell viability. Introduction of low amount $(5 \mathrm{~mol} \%)$ of amine- or ethyl-bearing silanes in the matrix formulation allowed for the recovery of the sensing capacity of the immobilized microalgae, without impacting on the response time (30 s). Porosimetry and ${ }^{29}$ Si Solid State NMR showed that the organic moieties are fully integrated into the inorganic network, tuning the ability of the target pollutant to diffuse and reach the encapsulated algae. This versatile strategy could be useful for the easy and fast assessment of contamination levels in polluted waters.
\end{abstract}

Keywords: Biosensors; microalgae; hybrid materials; contaminated water 


\section{Introduction}

Monitoring the impact of pollutants on the various forms of aquatic life is difficult because of the differential sensitivities of organisms to a given pollutant, and the inability to evaluate the long-term effects on ecosystems due to bioaccumulation in higher trophic levels [1]. In this context, bioassays using well-identified organisms as sensing elements represent a powerful approach for the measurement of toxicity in industrial effluents and environmental media. Many bioassays based on bacteria [2], plant tissues [3], animal cells [4] and micro-algae [5-7] have been developed over the last decades. In particular, the latter have been widely used for toxicity assays because of their high sensitivity associated with a good reproducibility of results [8]. Marine micro-algae are particularly promising as they have often developed specific response to organic and inorganic pollutants, being also able to remove heavy metals and certain toxic organic compounds without creating a secondary pollution [9].

In order to develop devices that are simple to use and able to stabilize biological sensing elements, it has been proposed to immobilize microorganisms within solid supports, a process called bioencapsulation [10]. The immobilization conditions have to be compatible with the survival of the cells and the preservation of the biological activity involved the sensing event [11]. Interest in the bio-encapsulation process has initially focused on gels formed by bioorganic polymers, for obvious reasons of cyto/biocompatibility, and then in matrices based on synthetic polymers [12]. However, encapsulation in polymers has certain disadvantages, in particular in terms of (bio)chemical and physical stability and formation of macroporous gels favoring cell leaching. The use of inorganic matrices obtained via the sol-gel process is another useful method as it provides access to gels with controlled porosity that can show better chemical and mechanical stability [13-16]. Moreover most cells do not have an enzymatic system capable of degrading silica, favoring long-term preservation of the host. 
Several micro-algal biosensors based on the sol-gel bioencapsulation process have already been described [17-20]. However, it would be useful to develop a versatile platform that could be easily adapted to the nature of the cell and of the targeted pollutants. This calls for a better understanding of the relationships between sol-gel materials, micro-organisms and toxic species. In this context, we have selected here three different microalgal species and studied their response towards three widespread pollutants, cadmium, lead and anthracene, first in suspension then within silica nanocomposite matrices prepared by an aqueous route [21]. The response of the microalgae was monitored by chlorophyll a fluorescence and ATP-metry. We found out that the chemical modification of the host material allows to achieve the fast detection of the pollutants, in a matrix- and cell-dependent manner. Analyses of the organically doped matrices by porosimetry and solid state NMR offer a detailed description of their chemical and structural features, explaining how a minor introduction of organosilanes can have a major impact on their affinity for pollutants and ultimately, on the cell response to their presence.

\section{Experimental}

\section{Cell culture}

The used organisms are from the National Museum of Natural History (MNHN) in Paris. Two eukaryotic species, Chlorella vulgaris (CCAP 211/11b) and Euglena gracilis (ALCP 217) and one prokaryotic cyanobacteria, Anabaena flos-aquae (ALCP B24) were selected. A. flosaquae and C. vulgaris was grown in Bold's Basal (BB) medium at $\mathrm{pH} 7.2$, whereas E. gracilis was grown in a mineral medium at $\mathrm{pH} 3.6$ [22]. All culture media are sterilized by autoclaving $\left(121^{\circ} \mathrm{C}, 20 \mathrm{~min}, 220 \mathrm{kPa}\right)$ before use. The micro-algae kept in erlenmeyer flasks were placed in a growth chamber conditioned to $20.0 \pm 1.0^{\circ} \mathrm{C}$ and manually shaken once a day at least. The 
irradiance was adjusted to the optimal intensity for each strain through neon lights (30-60 $\mu \mathrm{mol}$ $\mathrm{m}^{-2} \mathrm{~s}^{-1}$ photosynthetic photon flux (PPF) for cyanobacteria, $40-70 \mu \mathrm{mol} \mathrm{m} \mathrm{m}^{-2} \mathrm{~s}^{-1}$ for green microalgae). Algae were maintained in nycthemeral cycles of 16 hours of illumination and 8 hours of darkness.

Immobilization method

Cell encapsulation was performed at ambient temperature according to the aqueous route of the sol-gel process [21], using sodium silicate and colloidal silica as precursors (Fig. 1). Sodium silicate $\left(\mathrm{Na}_{2} \mathrm{SiO}_{3},[\mathrm{Si}]=0.16 \mathrm{M}, 1 \mathrm{~mL}\right)$ and LUDOX® $\mathrm{HS}-40(12 \mathrm{~nm} \mathrm{SiO}$ particles, [Si] $=$ $1.66 \mathrm{M}, 1 \mathrm{~mL}$ ) purchased from Aldrich, were mixed to obtain a homogeneous silica solution. A $\mathrm{HCl}$ solution $(4 \mathrm{M})$ was then added dropwise to reach $\mathrm{pH}$ 6. An algal solution $(1 \mathrm{~mL})$ containing ca. $10^{7}$ cells $/ \mathrm{mL}$ was immediately introduced under stirring at $300 \mathrm{rpm}$. The $\mathrm{pH}$ was controlled again and adjusted to $\mathrm{pH}$ 6. The resulting solution was put in transparent cuvettes (1 $\mathrm{cm}$ width). The cellularized gel was left to age for 24 hours at $20^{\circ} \mathrm{C}$, resulting in a silica monolith. Hybrid matrices were prepared following the same procedure except for the introduction of $5 \mathrm{~mol} \%$ (relative to total $\mathrm{Si}$ content) of aminopropyl-triethoxysilane $\left(\mathrm{Si}\left(\mathrm{OC}_{2} \mathrm{H}_{5}\right)_{3} \mathrm{C}_{3} \mathrm{H}_{6} \mathrm{NH}_{2}\right.$, APTMS) or ethyl-triethoxysilane $\left(\mathrm{Si}\left(\mathrm{OC}_{2} \mathrm{H}_{5}\right)_{3} \mathrm{C}_{2} \mathrm{H}_{5}\right.$, ETES) in the silica precursor mixture before cell suspension addition.

\section{Effect of pollutants on biological activity}

The effect of toxic chemicals on micro-algae was tested with cadmium and lead as heavy metals and anthracene as organic pollutant. Cadmium and lead, together with mercury, have been identified as the most toxic heavy metals and their effect on environment has been widely studied [23,24]. Anthracene belongs to the family of polycyclic aromatic hydrocarbons (PAHs), 
that are pollutants found in all parts of both aquatic and terrestrial ecosystems and their accumulation also causes important troubles [25].

The stock solutions of $\mathrm{Cd}\left(\mathrm{NO}_{3}\right)_{2} \cdot 4 \mathrm{H}_{2} \mathrm{O}$ and $\mathrm{Pb}\left(\mathrm{NO}_{3}\right)_{2}$ from Sigma Aldrich and Anthracene $\left(\mathrm{C}_{14} \mathrm{H}_{10}\right)$ from Prolabo were prepared with MilliQ ultrapure water and all test solutions were prepared from the stock by dilution in Milli-Q water immediately before use. 1 $\mathrm{mL}$ of the test solutions (or $1 \mathrm{~mL}$ of distilled water for control samples) was added to $3 \mathrm{~mL}$ of cell suspension or deposited on the top of silica gel monoliths of the same volume. Pollutants were tested at final concentration of $1,5,10,50,100$ and $500 \mu \mathrm{M}$. The exposure time was set to $30 \mathrm{~s}$ and 30 minutes. After this delay, the photosynthetic activity was determined by measuring the fluorescence intensity of chlorophyll a $\left(\lambda_{\mathrm{exc}}=640 \mathrm{~nm} ; \lambda_{\mathrm{em}}=680 \mathrm{~nm}\right)$. The rate of increase or inhibition in fluorescence after the exposure was determined as the difference between the variation of fluorescence in the presence of analyte and variation of fluorescence for control (in \%). It was checked that no interference could arise between the fluorescence spectrum of anthracene and that of chlorophyll a pigments.

The titration of ATP in cells is particularly interesting because it provides informations about their metabolic activity. ATP-metry consists in assaying ATP produced by the cells during respiration. ATP content allows to estimate the microbiological biomass because this energy source is present in all living cells and the rate of ATP per cell remains relatively constant [26]. It was recently shown that ATP-metry is well-adapted to monitor the viability of silica-encapsulated cells [27]. Values are given in \% of variation compared to cells in a pollutant-free medium.

All experiments were performed in triplicate and results were expressed as the arithmetic mean \pm standard deviation.

Materials characterization 
Silica aerogels were prepared by supercritical drying of the hydrogels. In a first step, the hydrogels were dehydrated by a series of immersion (15 min each) in aqueous solutions containing 50, 70 and $90 \%$ ethanol, followed by two immersions in absolute ethanol (96\%). Then the recovered samples were introduced in the cold chamber $\left(10^{\circ} \mathrm{C}\right)$ of a Baltec CPD 030 equipment and ethanol was slowly replaced by liquid $\mathrm{CO}_{2}$ using several injection/removal cycles. Once all ethanol was removed, the chamber was heated to $40^{\circ} \mathrm{C}$ and the $\mathrm{CO}_{2}$ in the supercritical state was slowly removed.

The $\mathrm{N}_{2}$ adsorption-desorption isotherms of aerogels were obtained at $77 \mathrm{~K}$ using a Belsorp-Max instrument from MicrotracBEL. The specific surface areas $S_{B E T}$ and corresponding $C_{B E T}$ constant were calculated according to the Brunauer-Emmett-Teller (BET) method using adsorption data in the relative pressure range from 0.05 to 0.25 whereas the pore size distribution and average pore size $D p$ estimated using the Barret-Joyner-Halenda (BJH) method by analyzing the desorption branch.

Solid state NMR studies were performed on a Bruker Avance III spectrometer operating at $300 \mathrm{MHz}$ for ${ }^{1} \mathrm{H}$ and $60 \mathrm{MHz}$ for ${ }^{29} \mathrm{Si} .7 \mathrm{~mm}$ zirconia rotors were spun at $5 \mathrm{kHz}$ using a broadband dual resonance ${ }^{1} \mathrm{H}-\mathrm{X}$ Magic Angle Spinning (MAS) probe. In the case of quantitative High Power DECoupling (HPDEC) experiments and qualitative Cross-Polarization (CP), SPINAL64 decoupling was applied during acquisition $\left(v_{1 \mathrm{H}}=52 \mathrm{kHz}\right)[28] .{ }^{29} \mathrm{Si} \mathrm{HPDEC}$ spectra were recorded using a $30^{\circ}$ pulse and a recycle delay of $60 \mathrm{~s}$ and $\sim 960$ transients. $\left\{{ }^{1} \mathrm{H}\right\}-{ }^{29} \mathrm{Si} \mathrm{CP}$ experiments were carried out with a $90^{\circ}$ pulse a recycle delay of $1 \mathrm{~s}$, a contact time of $3 \mathrm{~ms}$ and 2048 transients.. Two-dimensionnal (2D) HETeronuclear CORrelation with ${ }^{1} \mathrm{H}$ homonuclear decoupling $\left\{{ }^{1} \mathrm{H}\right\}-{ }^{29}$ Si DUMBO-HETCOR experiments were performed at $4924 \mathrm{~Hz}$ MAS rate with $1 \mathrm{~s}$ recycle delay, $3 \mathrm{~ms}$ contact time, $24 \mu \mathrm{s}$ DUMBO pulse at $v_{1 \mathrm{H}}=66 \mathrm{kHz}, 32$ slices and 256 transients [29]. An exponential line broadening of $50 \mathrm{~Hz}$ for ${ }^{29} \mathrm{Si}$ and a cosinus multiplication in ${ }^{1} \mathrm{H} 2 \mathrm{D}$ dimension were applied, respectively. 


\section{Results}

Effect of pollutants on cell suspensions

The inhibition rate of fluorescence emission was evaluated immediately after the exposition of micro-algae to pollutants (30 s) and after 30 minutes. Results for both times are similar and data shown here and afterwards are after 30 s of exposition (Fig. 2a-c and Electronic Supplementary Material Fig. S1 for selected fluorescence spectra). For A. flos-aquae, the inhibition of the fluorescence emission was observed even for the lowest tested concentration $(1 \mu \mathrm{M})$ of pollutants (see data for low pollutant concentration in Electronic Supplementary Material Fig. S2). Values for the various pollutants were rather similar, in the $20-22 \%$ range. The inhibition extent increased sharply with the increasing pollutant concentration to reach $51.5 \%, 34.5 \%$ and $42.5 \%$ for $\mathrm{Cd}(\mathrm{II}), \mathrm{Pb}(\mathrm{II})$ and anthracene, respectively, at $500 \mu \mathrm{M}$. The inhibition rates of C. vulgaris at $1 \mu \mathrm{M}$ after exposition to $\mathrm{Cd}(\mathrm{II})$ and $\mathrm{Pb}(\mathrm{II})$ were $29.5 \%$ and $26.0 \%$ respectively. For anthracene a slightly negative variation $(-0.14 \%)$ was recorded suggesting an increase of fluorescence emission after the exposition of micro-algae to the PAH pollutant but these values remained within the measurement error. The inhibition rates reached a plateau for $100 \mu \mathrm{M}$ for anthracene and $\mathrm{Pb}$ (II) and continue to increase with an increasing concentration of $\mathrm{Cd}$ (II). At $500 \mu \mathrm{M}$, this micro-algae showed a higher sensitivity for $\mathrm{Cd}(\mathrm{II})$ than for $\mathrm{Pb}(\mathrm{II})(47.0 \%$ and $37.0 \%)$ and a slight decrease in fluorescence was observed for anthracene (- $4 \%)$. Finally for E. gracilis, the inhibition rate increased sharply with increasing concentration of $\mathrm{Cd}(\mathrm{II})$ from $29.5 \%$ at $1 \mu \mathrm{M}$ to $42.0 \%$ at $500 \mu \mathrm{M}$. For $\mathrm{Pb}(\mathrm{II})$ and anthracene, the inhibition rates were negligible $(<0.5 \%)$ at $1 \mu \mathrm{M}$, and remains very low even at $500 \mu \mathrm{M}$ (ca. $2 \%)$.

The evolution of ATP produced by different micro-algae in the response to different pollutants was also followed (Fig. 2d-f). For A. flos-aquae a decrease in ATP production was observed 
with the increase of pollutants concentration, especially for $\mathrm{Cd}(\mathrm{II})$. For $C$. vulgaris no variation in the ATP level was noted for anthracene, and $\mathrm{Cd}(\mathrm{II})$ presented a higher effect than $\mathrm{Pb}(\mathrm{II})$ on the ATP production. Finally, E. gracilis exhibited a constant production of ATP in response to $\mathrm{Pb}(\mathrm{II})$ and anthracene, but an important decrease of the ATP level was noted in the presence of Cd(II). These results are in excellent agreement with the previous data obtained by measuring fluorescence inhibition rates.

Effect of pollutants on algal cells encapsulated in hybrid silica matrices

The three algal species were first encapsulated in a pure silica matrix. In all cases, the fluorescence intensity after $24 \mathrm{~h}$ of ageing was similar to that of the cell suspensions, indicating no significant detrimental effect of the encapsulation process on the photosynthetic activity of the cells. When $1 \mathrm{~mL}$ of pollutant solution at $10 \mu \mathrm{M}$ was put in contact with the cell-containing gels, no significant change in the fluorescence intensity could be observed, whatever the algal species or the toxic element (Fig. 3a-c and selected spectra in Electronic Supplementary Material Fig. S3). Since the initial cell viability was preserved, we hypothesized that the silica matrix inhibited in some way the transfer of $\mathrm{Cd}, \mathrm{Pb}$ and anthracene from the supernatant solution to the encapsulated cells, most likely due to interactions of pollutants with the internal surface of the pores. Hybrid matrices incorporating ETES bearing an ethyl group or APTMS bearing an aminopropyl side chain as a surface agents were therefore prepared and used for cell encapsulation. For all cells and both matrices, no modification of the fluorescence intensity could be detected after $24 \mathrm{~h}$ of encapsulation compared to cell suspension and pure silicaencapsulated cells, indicating that these organically doped hosts were still fully compatible with the preservation of microalgae biological activity.

Fluorescence intensity curves are shown in Fig. 3b-d with selected spectra provided in Electronic Supplementary Material Fig. S3. The resulting inhibition rates are gathered in Table 
1. In the amine-modified matrices, we noted no response of the cells to heavy metals. The effect of anthracene followed the same trend as for cell suspensions, except for a systematic decrease of inhibition rate by ca. $5 \%$, leading to negligible inhibition rates for E. gracilis. Such a limited decrease indicates that anthracene is diffusing almost freely within the pores of the hybrid silica network. This hypothesis is strengthened by the observation that these responses were observed less than 1 minute after pollutant addition. ATP assays were also carried out for encapsulated cells at different concentrations of anthracene. These results are in agreement with inhibition rates, showing the decrease of ATP level for A. flos aquae (see Electronic Supplementary Material Fig. S4). In contrast to APTMS, the silica gel functionalized with ETES led to the absence of response for all cells in the presence of anthracene. However, all entrapped cells had clear responses to heavy metals. As observed for the previous matrix, the inhibition rates were systematically but only slightly (less than 5\%) smaller for immobilized cells compared to cells in suspension, leading to a non-measurable response of E. gracilis to $\mathrm{Pb}(\mathrm{II})$. Here again, the response was fast and stable over 30 min of exposition of all cells with different pollutants. ATP-metry also confirmed these trends (see Electronic Supplementary Material Fig. S4).

Characterization of the hybrid matrices

In order to understand the effect of the addition of silane coupling agents on the silica structure, the gels were converted into aerogels using supercritical drying and characterized by nitrogen sorption at $77 \mathrm{~K}$ (Fig. 4a). The shape of the isotherms gives information about the textural characteristics of materials [30]. The isotherm obtained for silica gel with APTMS is of type II, corresponding to non-porous or macroporous materials [30]. For other samples, i.e. unmodified silica gel and silica gel with ETES, we obtained type IV isotherms, corresponding to mesoporous materials $(2-50 \mathrm{~nm})$. 
Calculation of the specific surface area $S_{B E T}$ and pore size distribution (Fig. $\mathbf{4 b}$ ) from these data confirm that the presence of silanes has changed the gel porous structure to various extents. APTMS has a negligible impact on the specific surface area of the inorganic network $\left(S_{B E T}=190 \mathrm{~m}^{2} \cdot \mathrm{g}^{-1}\right.$ and $185 \mathrm{~m}^{2} \cdot \mathrm{g}^{-1}$ for pure silica and APTMS-silica aerogel, respectively). However, the pore size distribution is broadened and extends up to the macropore domain ( $\mathrm{ca}$. $50 \mathrm{~nm}$ ), in agreement with the sorption isotherm shape. In contrast, upon ETES addition, the specific surface area increases by ca. $30 \%\left(S_{B E T}=255 \mathrm{~m}^{2} \cdot \mathrm{g}^{-1}\right)$ compared to the pure silica matrix. In parallel, the pore size distribution is shifted towards smaller pores, $D p$ value being ca. $3 \mathrm{~nm}$ compared to $c a .5 \mathrm{~nm}$ for pure silica. Examining the $C_{B E T}$ parameter provides an additional information. This parameter is related to the affinity of $\mathrm{N}_{2}$ for sorbent and can be used to compare the hydrophilic/hydrophobic character of pore surfaces for closely-related materials, such as hybrid silica-based systems [31-33]. In this context, the pure silica matrix with the highest $C_{B E T}$ value $\left(C_{B E T}=110\right)$ was the more hydrophilic, followed by the APTMSmodified one $\left(C_{B E T}=90\right)$ whereas ETES had the more hydrophobic surface $\left(C_{B E T}=50\right)$.

To understand further the modification of silica gels by silane coupling agents, they were characterized by ${ }^{1} \mathrm{H}$ and ${ }^{29} \mathrm{Si}$ solid state NMR (nuclear magnetic resonance) spectroscopy [34]. The quantitative ${ }^{29} \mathrm{Si}$ HPDEC NMR spectra of the nanocomposite silica gel and the two modified gels show a signal at $-111 \mathrm{ppm}$ with similar intensity that corresponds to $\mathrm{Q}^{4}\left(\mathrm{Si}(\mathrm{OSi})_{4}\right.$ silicate species) and a weaker signal at $-101 \mathrm{ppm}$ coming from $\mathrm{Q}^{3}\left(\mathrm{Si}(\mathrm{OSi})_{3} \mathrm{OH}\right)$ species (Fig. 5A). Some signals with very low intensities could be distinguished at higher chemical shifts for the ETES sample (Fig. 5A(c)). In order to better characterize these signals, $\left\{{ }^{1} \mathrm{H}\right\}-{ }^{29} \mathrm{Si} \mathrm{CP}$ was used as a selective but non-quantitative tool (Fig. 5B). Indeed, using this pulse sequence, signals are enhanced according to their ${ }^{1} \mathrm{H}$ proximity. Thus, for the pure silica gel, the $\mathrm{Q}^{4}$ and $\mathrm{Q}^{3}$ peaks now have a similar intensity. For silica gel with APTMS and ETES, these signals are also present with similar intensities but stronger signals are visible at 
approximately - 46, - 56 and - $66 \mathrm{ppm}$, corresponding to $\mathrm{T}^{1}, \mathrm{~T}^{2}$ and $\mathrm{T}^{3}$ species, respectively. These species correspond to $\mathrm{Si}$ atoms of the silane molecules linked to one organic group and forming 1, 2 or $3 \mathrm{O}-\mathrm{Si}$ bonds with other $\mathrm{Si}$ atoms. One should notice that for all silanes, the more condensed species $\left(\mathrm{T}^{3}\right)$ seem to prevail over less condensed ones, suggesting a good integration of these molecules to the silica network. When the different samples are compared, the relative peak intensity suggest that ETES is more abundant than APTMS. Attempts to perform thermogravimetric analyses of the different samples show no significant difference in weight loss between the pure and hybrid materials, which could be expected for the low amount of introduced silanes. Accordingly, FTIR spectra did not allow for an unambiguous characterization of the grafted moieties.

In a step further, we asked if the silane molecules were bounded to the silicate species or to the Ludox particles, or both. We focused on ETES-containing samples since this silane was more abundant in the silica network than APTMS. For this, we prepared two additional samples: a pure Ludox system and a ETES-silicate gel. Noticeably attempts to obtain gels from ETES-silicates mixture were unsuccessful. We recorded ${ }^{29} \mathrm{Si}$ HPDEC spectra of these additional samples (Fig. 5A(d,e)). Considering first the $\mathrm{Q}^{\mathrm{n}}$ species in the absence of ETES, the spectrum of the Ludox sample (Fig. 5A(d)) is very similar to the silicate-Ludox sample (Fig. 5A(a)), denoting that this spectrum is dominated by Ludox core particles. On the contrary, when studying ETES-silicate system without Ludox, the silicon network is much less condensed with an intense $\mathrm{Q}^{3}$ signal. Considering $\mathrm{T}^{\mathrm{n}}$ species, the lower intensity of the corresponding peak suggests that they are incorporated in a lower amount compared to the ETES-silicates-Ludox sample. Altogether these data suggest that ETES interacts with both silicates and Ludox. However the first situation seems to prevail, reflecting the fact that the probability for the three reactive $\mathrm{Si}-\mathrm{O}$ groups of ETES to form bonds with 3 other $\mathrm{Si}-\mathrm{O}$ species is higher in silicate 
solutions, containing tetravalent silicic acid $\mathrm{Si}(\mathrm{OH})_{4}$ species, than on Ludox nanoparticles where a maximum of 3 silanols groups on the surface can be involved in the grafting reaction.

To go further in this analysis, we established 2D maps of interactions between ${ }^{1} \mathrm{H}$ and ${ }^{29} \mathrm{Si}$ NMR signals, as it allows to study the connectivity among all species (Fig. 6). The presence of signals at the crossing of vertical dashed lines corresponding to specific peaks in the ${ }^{29} \mathrm{Si}$ spectrum (projection shown on the top) and of horizontal dashed lines corresponding to specific peaks in the ${ }^{1} \mathrm{H}$ spectrum (projection shown on the right) indicate that the chemical species corresponding to these two peaks can exchange magnetization through space, i.e. are in close proximity. The signal intensity is shown using a color scale, from blue (weak) to red (strong). For Ludox sample, $\mathrm{Q}^{2}, \mathrm{Q}^{3}$ and $\mathrm{Q}^{4}$ species are correlated with protons in the 2-8 ppm region (Fig. 6a), corresponding to silanol SiO- $\underline{\mathrm{H}}$ groups. In silica nanoparticles, $\mathrm{Q}^{4}$ species are located within the core of the particles. $\mathrm{Q}^{3}$ species are mainly located on their surface, although the core structure is not fully condensed and can also incorporate some $\mathrm{OH}$ on $\mathrm{Q}^{3}$ silicon atoms. Finally, $\mathrm{Q}^{2}$ species are expected to be localized on the surface in a very large majority. As a result, $\mathrm{Q}^{2}$ and $\mathrm{Q}^{4}$ exhibit different ${ }^{1} \mathrm{H}$ signals. While core $\mathrm{OH}$ near $\mathrm{Q}^{4}$ are at $3.7 \mathrm{ppm}$, surface $\mathrm{OH}$ near $\mathrm{Q}^{2}$ are at $4.7 \mathrm{ppm}$, indicating stronger H-bonds [35]. Similarly, core $\mathrm{Q}^{4}$ and core $\mathrm{Q}^{3}{ }^{29} \mathrm{Si}$ chemical shifts (-111.3 and $-101.5 \mathrm{ppm}$, respectively) are slightly different from near surface $\mathrm{Q}^{4}$ and surface $\mathrm{Q}^{3}$ (-109.8 and -99.9 ppm, respectively), as also evidenced when superimposing CP and HPDEC spectra (not shown). Thus, there is a complex network of interactions between silicon $\mathrm{Q}^{3}$ atoms and protons, resulting in a broad cross-peak region. Nevertheless, it can be noted that the correlation signal is more intense for $\mathrm{Q}^{3}$ species than for $\mathrm{Q}^{4}$, in agreement with the presence of one remaining $\mathrm{SiOH}$ group in the former.

Moving to the ETES-silicate system, the ${ }^{1} \mathrm{H}$ spectrum shows an additional band at $1.2 \mathrm{ppm}$ corresponding to the aliphatic protons of the $\mathrm{C}_{3} \mathrm{C}_{2}-\mathrm{Si}$ ethyl chain of the organosilane (Fig. 6b). Concerning the ${ }^{1} \mathrm{H}$ peak at $4.5 \mathrm{ppm}$, it exhibits a much narrower 
lineshape than on Ludox sample, which would suggest H-bonded water rather than $\mathrm{OH}$. Indeed, it should be reminded that silicates have non-protonated $\mathrm{Q}^{3}-\mathrm{O}^{-}$which can be involved into such a H-network. Considering the cross-peak region, $\mathrm{Q}^{4}$ species correlate mostly with the ethyl groups and $\mathrm{Q}^{3}$ with water although $\mathrm{Q}^{3}$-ethyl and $\mathrm{Q}^{4}$-silanol correlations are also detected. This indicates that the organosilane is well incorporated within the silica network. Focusing on the $\mathrm{T}^{\mathrm{n}}$ region (-55.5 and $-63.0 \mathrm{ppm}$ on the ${ }^{29} \mathrm{Si}$ spectrum), we observed a strong correlation of the Si atoms of the organosilanes with their ethyl chain, as expected. Moreover, $\mathrm{Q}^{3}$-ethyl and $\mathrm{Q}^{3}$ water have noticeably different ${ }^{29} \mathrm{Si}$ chemical shifts (-101.5 and $-99.9 \mathrm{ppm}$, respectively). This suggests high cross-linking of ETES and silicates with the presence of ETES-rich hydrophobic pockets.

Finally, the ETES-silicates-Ludox material is mainly a superimposition of the two previous $2 \mathrm{D}$ spectra (Fig. 6c). Nevertheless, two additional observations can be made. First $\mathrm{T}^{\mathrm{n}}$ signals now show some cross-peaks at $\delta^{1} \mathrm{H}=4.5 \mathrm{ppm}$, which can correspond both to surface $\mathrm{OH}$ groups from Ludox and to water near silicate. Here it must be underlined that $\mathrm{Q}^{3}$ peak at $\delta^{1} \mathrm{H}=4.5 \mathrm{ppm}$ is not as sharp as on ETES-silicate sample, indicating either a lowr water amount or a decreased water mobility. When looking carefully to the 2D map, a correlation is present between $\mathrm{T}^{2}$ and $\mathrm{OH}$ at $\delta^{1} \mathrm{H}=3.7 \mathrm{ppm}$ which can only be attributed to core Ludox $\mathrm{OH}$ groups. This is a clear evidence that some ETES molecules are grafted at the surface of Ludox particles. Second, $\mathrm{Q}^{3}$ and $\mathrm{Q}^{4}$ species are both correlated with silanol and ethyl chains. Each of these four peaks exhibits a shoulder characteristic of multiple environments. One can thus identify both ETES-silicate and ETES-Ludox peaks. Altogether, it strongly supports our previous assumption that ETES is present both on the surface of Ludox particles and within the silicate network.

\section{Discussion}


Cell-based biosensing materials design relies on three elements: (i) an analyte-responsive cell, (ii) a solid-state support for these cells and (iii) a robust (i.e. sensitive, reproducible and, if possible, easily available) detection method.

Prokaryotic and eukaryotic microalgae are well-known to be high sensitive to heavy metal exposure but their response varies with the species and, similarly, various metals may cause different responses within same species. Our study confirmed this fact: (i) the highest effect was found for Cd(II) for all micro-algae, with the cyanobacteria being the more sensitive to this species (ii) $\mathrm{Pb}(\mathrm{II})$ presented a similar effect on A. flos-aquae, and C. vulgaris while $E$. gracilis showed no sensitivity to this pollutant. The half maximal inhibitory concentration ( $\left.\mathrm{IC}_{50}\right)$ of cadmium and lead towards A. flos-aquae was reported to be $1.25 \mu \mathrm{M}$ and $5 \mu \mathrm{M}$, respectively, after 3 days of contact [36]. We found here an $\mathrm{IC}_{50}$ of $500 \mu \mathrm{M}$ for $\mathrm{Cd}$ and the 50 $\%$ inhibition threshold was not reached for $\mathrm{Pb}$ at this concentration but after only $30 \mathrm{~s}$, making direct comparison difficult. From a physiological point of view, it was shown that Cd was accumulated in A. flos-aquae, resulting in the alteration of the ultrastructure of thylakoids [37]. These reports correlate very-well with our observations of the strong perturbation of the photosynthetic pigments of $A$. flos-aquae in the presence of $\mathrm{Cd}(\mathrm{II})$. The inhibition of growth of the green micro-alga $C$. vulgaris by heavy metals in both dose and time dependent-manner was also reported [38]. For example, in treatments at $5 \mu \mathrm{M}, \mathrm{Cd}(\mathrm{II})$ was found more toxic than $\mathrm{Pb}(\mathrm{II})$ after $24 \mathrm{~h}$ [39]. Here, the difference in the impact of the two ions became significant at higher doses $(100 \mu \mathrm{M})$, as expected for a much shorter exposition time. Finally, our study of E. gracilis showed a high sensitivity for $\mathrm{Cd}(\mathrm{II})$ and almost no response to $\mathrm{Pb}(\mathrm{II})$ exposition. This result confirmed the work of Navarro et al. [40], showing that Cd(II) induced significant toxic effects to this species above $50 \mu \mathrm{M}$ while $\mathrm{Pb}^{2+}$ was almost ineffective up to $1000 \mu \mathrm{M}$.

It has been suggested that the hydrophobicity of low molecular weight PAHs, such as anthracene, allowing for its incorporation within cell membranes, is a key property driving their 
cytotoxic effect [41]. However, very few papers have described the effect of anthracene on micro-algae [42], none of them being related to species chosen in our study. A comparative study of three different species of cyanobacteria showed that anthracene at dose of $c a .150 \mu \mathrm{M}$ can decrease chlorophyll a amount down to $c a .80 \%$ after a 4-days exposure [43]. Our study showed that at this concentration the cyanobacteria A. flos-aquae react to anthracene with $c a$. $35 \%$ of inhibition rate after $30 \mathrm{~s}$, while E. gracilis seems not to be sensitive to this PAH. Finally for the green algae $C$. vulgaris, an increase in fluorescence was observed, suggesting that the stress induced by anthracene is different from the one induced by metal ions for this specific species.

In this context, ATP-metry reveals to be a highly complementary technique to understand the effect of the pollutants on the cellular activity. While chlorophyll a fluorescence gives information on the photosynthetic apparatus of the microalgae, the level of ATP within the cell reflects its global metabolism. The overall excellent correlation obtained here between these two techniques therefore evidences that the monitored decrease in fluorescent intensity is a reliable indication of the pollutant cytotoxicity. Meanwhile, the observed increase in fluorescence intensity upon anthracene addition to E. gracilis is not correlated to a significant modification of the ATP level, suggesting that for this microalgae anthracene interferes more specifically with the photosynthetic process.

Overall, we could show here that the selected algal cells could respond in a measurable manner to one or several of the tested pollutants in a short amount of time (less than $30 \mathrm{~s}$ ). They therefore constitute interesting organisms for the development of biosensors. In a next step, we have studied how these responses are affected by their encapsulation in silica gel. The purely inorganic material revealed to be well-adapted to cell immobilization, as both the chlorophyll a fluorescence and ATP production level were similar to that of cell suspensions after $24 \mathrm{~h}$. However, encapsulated cells showed no response to the addition of $\mathrm{Cd}(\mathrm{II}), \mathrm{Pb}$ (II) and 
anthracene added at a $10 \mu \mathrm{M}$ concentration. Such an effect could be expected for metal ions as their strong tendency to adsorb on the negatively-charged surface of silica are already wellknown [44] (Fig. 7a). However, the absence of response for anthracene was more surprising as its hydrophobic character makes it very unlikely to interact with the hydrophilic surface of the inorganic pores. In fact, one possible explanation is that the porous network of the silica gel is too hydrophilic to allow anthracene diffusion. This hypothesis is supported by a previous report showing that hydrophobic molecules produced by silica encapsulated cells were rapidly expelled from the inorganic network and accumulated in the gel supernatant [45].

The introduction of organosilanes within the sol-gel formulation appears as a suitable approach to address this issue. From a chemical perspective, the here-used nanocomposite silica gel is formed by the polymerization of silicates species (i.e. polysilicic acids, $\mathrm{OH}-\left(\mathrm{Si}_{x} \mathrm{O}_{y}(\mathrm{OH})_{z}\right)$ $\mathrm{OH})$ via condensation of silanol groups (eq. 1):

$\mathrm{OH}-\left(\mathrm{Si}_{x} \mathrm{O}_{y}(\mathrm{OH})_{z}\right)-\mathrm{OH}+\mathrm{OH}-\left(\mathrm{Si}_{x} \mathrm{O}_{y}(\mathrm{OH})_{z}\right)-\mathrm{OH} \Leftrightarrow \mathrm{OH}-\left(\mathrm{Si}_{2 x} \mathrm{O}_{2 y+1}(\mathrm{OH})_{2 z}\right)-\mathrm{OH}+\mathrm{H}_{2} \mathrm{O}$

The colloidal silica nanoparticles $\left(\mathrm{SiO}_{2}\right)_{\mathrm{c}}$ are trapped within this network and the condensation between the silanol groups of the particle surface and silicates is also possible (eq. 2) [46]:

$\left(\mathrm{SiO}_{2}\right)_{\mathrm{c}^{-}} \mathrm{OH}+\mathrm{OH}-\left(\mathrm{Si}_{x} \mathrm{O}_{y}(\mathrm{OH})_{z}\right)-\mathrm{OH} \Leftrightarrow\left(\mathrm{SiO}_{2}\right)_{\mathrm{c}^{-}} \mathrm{O}-\left(\mathrm{Si}_{x} \mathrm{O}_{y}(\mathrm{OH})_{z}\right)-\mathrm{OH}$

When organosilanes $\left(\mathrm{R}-\mathrm{Si}\left(\mathrm{OC}_{2} \mathrm{H}_{5}\right)_{3}\right)$, with $\mathrm{R}=\mathrm{C}_{3} \mathrm{H}_{6} \mathrm{NH}_{2}$ (APTMS) or $\mathrm{C}_{2} \mathrm{H}_{5}$ (ETES) are introduced in the aqueous formulation, they first undergo hydrolysis (eq. 3):

$\mathrm{R}-\mathrm{Si}\left(\mathrm{OC}_{2} \mathrm{H}_{5}\right)_{3}+3 \mathrm{H}_{2} \mathrm{O} \Leftrightarrow \mathrm{R}-\mathrm{Si}(\mathrm{OH})_{3}+3 \mathrm{C}_{2} \mathrm{H}_{5} \mathrm{OH}$

These species can then condense with silicates (eq. 4)

$\mathrm{R}-\mathrm{Si}(\mathrm{OH})_{3}+\mathrm{OH}-\left(\mathrm{Si}_{x} \mathrm{O}_{y}(\mathrm{OH})_{z}\right)-\mathrm{OH} \Leftrightarrow \mathrm{R}-\left(\mathrm{Si}_{x+1} \mathrm{O}_{y+1}(\mathrm{OH})_{z+2}\right)-\mathrm{OH}+\mathrm{H}_{2} \mathrm{O}$

and/or with silica nanoparticles (eq. 5).

$\left(\mathrm{SiO}_{2}\right)_{\mathrm{c}}-\mathrm{OH}+\mathrm{R}-\mathrm{Si}(\mathrm{OH})_{3} \Leftrightarrow\left(\mathrm{SiO}_{2}\right)_{\mathrm{c}}-\mathrm{Si}(\mathrm{OH})_{2}-\mathrm{R}+\mathrm{H}_{2} \mathrm{O}$

Thus, they can perturb both the silicate-based matrix and the silicate/colloidal silica interface. 
When APTMS was incorporated in small amount to the gel, as evidenced by solid state NMR, the encapsulated cells recovered their initial sensitivity to anthracene whereas metal ions still had no effect on these cells. From a structural point of view, this silane only slightly decreases the specific surface area of the silica network while inducing the formation of much larger pores, two evolutions that cannot explain the observed modifications in pollutant diffusion. From a chemical perspective, additional amino groups can contribute to $\mathrm{Cd}(\mathrm{II})$ and $\mathrm{Pb}$ (II) binding to the surface, explaining why they still cannot be detected by the immobilized cells [47] (Fig. 7b). Considering anthracene, it is interesting to note that the $C_{B E T}$ value is smaller in APTMS-containing gels compared to pure silica gels. This means that the hydrophilicity of the pores has decreased and may therefore become compatible with the diffusion of anthracene from the supernatant to the encapsulated cells.

ETES addition of the sol-gel formulation led to its efficient incorporation within the inorganic network. 2D correlation NMR spectra indicate that this silane is incorporated not only in the silicate matrix (eq. 4) but also at the surface of the nanoparticles (eq. 5). This can explain why, despite the low amount of introduced ETES, it can induce significant changes in the porous structure and surface chemistry of the nanocomposite hydrogel. As expected, the incorporation of ETES also leads to a $C_{B E T}$ value that is smaller to that of both pure silica gels and APTMS-modified materials. Noticeably, $C_{B E T}$ value for a mesoporous silica material after calcination was reported to be $c a$. 95, close to the value (110) found for the pure silica gel, while after grafting propylsilyl groups it decreased to 68 , in fair agreement with the $C_{B E T}=50$ value found here for the ETES-modified aerogel. ${ }^{33}$ In this condition, the surface adsorption of the metals is hindered allowing for their diffusion and detection by the encapsulated cells (Fig. 7c). On the contrary, the more hydrophobic character of the surface is expected to favor anthracene adsorption, hindering its efficient transport to the entrapped organisms. 
Having identified pollutant-sensitive cells and engineered encapsulation matrices compatible with their preserved activity, the question of the detection method must be raised. On the one hand, the correlation between ATP-metry and fluorescence measurements demonstrated that the latter provide a reliable indication of the presence of toxic species in water. Moreover, due to the good transparency of the gels, such an optical method is welladapted to silica-encapsulated cells. However, two important points need to be investigated further. First, the smallest concentration of pollutant studied here is $1 \mu \mathrm{M}$. While the response of cell suspension was already significant (ca. $20 \%$ of fluorescence inhibition), investigation of lower doses is necessary to determine the limit of detection of the method. Noticeably, although the encapsulation matrix, once suitably modified, led to a maximum decrease of $5 \%$ in the fluorescence intensity in the presence of pollutants at $10 \mu \mathrm{M}$, it can be expected that surface adsorption phenomena may become more crucial when this concentration is decreased. This can impact on the limit of detection as well as on the existence of a linear dose-response regime. Hence the here-developed materials may at this stage be more useful as indicators of a global level of contamination rather than for the precise determination of a given pollutant. In this context, the choice of appropriate organosilanes should allow an easy discrimination between inorganic and organic contaminants. Another important aspect that need to be investigated is the stability of the cellularized material. Whereas previous reports have shown a good preservation of silica-encapsulated over month-periods in a wet state, the possibility to obtain a stable and active system in the dry state remains highly challenging.

\section{Conclusion}

Microalgae-based solid biosensors allowing for the rapid detection of toxic metals and organics in water were successfully obtained via a hybrid sol-gel chemistry approach. Of particular 
interest is the demonstration that the introduction of small amounts of organosilanes can have a strong influence on the transfer of pollutants from the solution to the encapsulated cells without perturbing their biological activity. This points out that the design of whole cell biosensors based on immobilization processes requires to pay a balanced attention to the biological and material partners, ultimately establishing new bridges between bio- and chemiodiversity.

\section{Acknowledgments}

N.B. PhD was funded by the French Ministry for Superior Education and Research. The authors thank Pr G. Thouand (GEPEA, Université de Nantes) and Dr B. Lebeau (ISMM, Université de Haute Alsace) for fruitful discussions.

\section{Conflict of Interest}

The authors declare that they have no conflict of interest.

\section{References}

[1] Torres MA, Barros MP, Campos SCG, Pinto E, Rajamani S, Sayre RT, Colepicolo P. Biochemical biomarkers in algae and marine pollution. Ecotox Environ Safe. 2008;71:1- 15.

[2] Trang PTK, Berg, M, Viet PH, Mui NV, van der Meer JR. Bacterial Bioassay for Rapid and Accurate Analysis of Arsenic in Highly Variable Groundwater Samples. Environ Sci Technol. 2005;39:7625-30.

[3] Augusto J, Brenneman TB. Assessing Systemicity of Peanut Fungicides Through Bioassay of Plant Tissues with Sclerotium rolfsii. Plant Dis. 2012 ;96:330-7.

[4] Avishai N, Rabinowitz C, Moiseeva E, Rinkevich B. Genotoxicity of the Kishon River, Israel: The application of an in vitro cellular assay. Mutat Res. 2002;518:21-37. 
[5] Durrieu C, Tran-Minh C, Chovelon JM, Barthet L, Chouteau C, Védrine C. Algal biosensors for aquatic ecosystems monitoring. Eur Phys J :Appl Phys. 2006 ;36 :205-9

[6] Scognamiglio V, Pezzotti G, Pezzotti I, Cano J, Buonasera K, Giannini D, Giardi MT. Biosensors for effective environmental and agrifood protection and commercialization: from research to market. Microchim Acta. $2010 ; 170: 215-25$

[7] Brayner R, Couté A, Livage J, Perrette C, Sicard, C Micro-algal biosensors. Anal Bioanal Chem 2011;401:581-97.

[8] Monteiro CM, Castro PML, Malcata FX. Metal uptake by microalgae: underlying mechanisms and practical applications. Biotechnol Prog. 2012;28:299-311

[9] Sánchez-Rodriguez I, Huerta-Diaz MA, Choumiline E, Holguın-Quinones O, ZertucheGonzález JA. Elemental concentrations in different species of seaweeds from Loreto Bay, Baja California Sur, Mexico: implications for the geochemical control of metals in algal tissue. Environ Poll. 2001;114:145-60.

[10] Gill I, Ballesteros A. Bioencapsulation within synthetic polymers (Part 2): non-sol-gel protein-polymer biocomposites. Trends Biotechnol. 2000;18:469-79.

[11] Depagne C, Roux C, Coradin T. How to design cell-based biosensors using the sol-gel process. Anal Bional Chem. 2011;400:965-76

[12] Moreno-Garrido I. Microalgae immobilization: Current techniques and uses. Biores Technol. 2008;99:3949-64.

[13] Böttcher H, Soltmann U, Mertig M, Pompe W. Biocers: ceramics with incorporated microorganisms for biocatalytic, biosorptive and functional materials development. J Mater Chem. $2004 ; 14: 2176-88$ 
[14] Rooke JC, Leonard A, Meunier CF, Su BL, Designing photobioreactors based on living cells immobilized in silica gel for carbon dioxide mitigation. ChemSusChem. 2011;4:1249-57. [15] Blondeau M, Coradin T. Living materials from sol-gel chemistry: current challenges and perspectives. J Mater Chem. 2012;22:22335-43.

[16] Dickson DJ, Ely RL. Silica sol-gel encapsulation of cyanobacteria: lessons for academic and applied research. Appl Microbiol Biotechnol. 2013;97:1809-19.

[17] Pena-Vazquez E, Maneiro E, Perez-Conde C, Moreno-Bondi MC, Costas E. Microalgae fiber optic biosensors for herbicide monitoring using sol-gel technology. Biosens Bioelectron. $2009 ; 24: 3538-43$.

[18] Darder M, Aranda P, Burgos-Asperilla L, Llobera A, Cadarso VJ, Fernandez-Sanchez C, Ruiz-Hitzky E. Algae-silica systems as functional hybrid materials. J Mater Chem. 2010;20:9362-69.

[19] Perullini M, Ferro Y, Durrieu C, Jobbagy M, Bilmes SA. Sol-gel silica platforms for microalgae-based optical biosensors. J Biotechnol. 2014;179:65-70.

[20] Pannier A, Soltmann U, Altenburger R, Schmitt-Jansen M. Alginate/silica hybrid materials for immobilization of green microalgae Chlorella vulgaris for cell-based sensor arrays. J Mater Chem B. 2014;2:7896-7910.

[21] Nassif N, Bouvet O, Rager MN, Roux C, Coradin T, Livage J. Living bacteria in silica gels. Nature Mater. 2002;1:42-4.

[22] Dahoumane SA, Yéprémian C, Djédiat C, Couté A, Fiévet F, Coradin T, Brayner R. Improvement of kinetics, yield, and colloidal stability of biogenic gold nanoparticles using living cells of Euglena gracilis microalga. J Nanopart Res. 2016;18:79.

[23] Järup L, Akesson A. Current status of cadmium as an environmental health problem. Toxicol Appl Pharmacol. 2009 ;238 :201-8.

[24] Flora G, Gupta D, Towari A. Toxicity of lead: A review with recent updates. Interdiscip 
Toxicol. 2012;5:47-58.

[25] Sverdrup LE, Krogh PH, Nielsen T, Kjaer C, Stenersen J. Toxicity of eight polycyclic aromatic compounds to red clover (Trifolium pratense), ryegrass (Lolium perenne), and mustard (Sinapsis alba). Chemosphere. 2003;53:993-1003

[26] Crouch SP, Kozlowski R, Slater KJ, Fletcher J. The use of ATP bioluminescence as a measure of cell proliferation and cytotoxicity. J Immun Methods. 1993;160:81-8.

[27] Blondeau M, Brayner R, Guyot F, Coradin T. Correlating biological methods to assess Escherichia coli bacteria viability in silica gels. Anal Methods. 2014;6:2429-31.

[28] Fung M, Khitrin AK, Ermolaev K. An Improved Broadband Decoupling Sequence for Liquid Crystals and Solids. J Magn Reson. 2000:142, 97-101.

[29] A. Lesage A, Sakellariou D, Hediger S, Elena B, Charmont P, Steuernagel S, Emsley L. Experimental aspects of proton NMR spectroscopy in solids using phase-modulated homonuclear dipolar decoupling. J. Magn Reson. 2003;163:105-13.

[30] Thommes M, Kaneko K, Neimark AV, Olivier JP, Rodriguez-Reinoso F, Rouquerol J, Sing KSW. Physisorption of gases, with special reference to the evaluation of surface area and pore size distribution (IUPAC Technical Report). Pure Appl Chem. 2015 ;87 :1051-69.

[31] Lassiaz S, Labarre D, Galarneau A, Brunel D, Mutin PH. Modification of silica by an organic monolayer in aqueous medium using octylphosphonic acid and aluminium species. $\mathbf{J}$ Mater Chem $2011 ; 21: 8199-205$.

[32] Bernardoni F, Fadeev AY. Adsoption and wetting characterization of hydrophobic SBA15 silica. J Colloid Interface Sci $2011 ; 356: 690-8$.

[33] Brunel D, Cauvel A, Di Renzo F, Fajula F, Fubini B, Onida B, Garrone E. Preferential grafting of alkoxysilane coupling agents on the hydrophobic portion of the surface of micelltemplated silica. New J. Chem. 2000; 24:807-13.

[34] Bonhomme C, Coelho C, Baccile N, Gervais C, Azaïs T, Babonneau F. Advanced solid 
state NMR techniques for the characterization of sol-gel derived materials. Acc Chem Res. $2007 ; 40: 738-46$.

[35] Gervais C, Coelho C, Azaïs T, Maquet J, Laurent G, Pourpoint F, Bonhomme C, Florian P, Alonso B, Guerrero G, Mutin PH, Mauri F. First principles NMR calculations of phenylphosphinic acid $\mathrm{C}_{6} \mathrm{H}_{5} \mathrm{HPO}(\mathrm{OH})$ : Assignments, orientation of tensors by local field experiments and effect of molecular motion. J Magn Reson 2007; 187, 131-40.

[36] Heng LY, Jusoh K, Ling CHM, Idris M. Toxicity of single and combinations of lead and cadmium to the cyanobacteria Anabaena flos-aquae. Bull Environ Contam Toxicol. $2004 ; 72: 373-379$

[37] Surosz W, Palinska KA. Effects of Heavy-Metal Stress on Cyanobacterium Anabaena flosaquae. Arch Environ Contamin Toxicol 2004;48:40-8.

[38] Bajguz A. Suppression of Chlorella vulgaris Growth by Cadmium, Lead, and Copper Stress and Its Restoration by Endogenous Brassinolide. Arch Environ Contamin Toxicol $2011 ; 60: 406-16$.

[39] Ouyang HL, Kong XZ, He W, Qin N, He QS, Wang Y, Wang R, Xu FL. Effects of five heavy metals at sub-lethal concentrations on the growth and photosynthesis of Chlorella vulgaris. Chin Sci Bull. 2012;57:3363-70.

[40] Navarro L, Torres-Marquez ML, Gonzalez-Moreno S, Devars S, Hernandez R, MorenoSanchez R. A comparison of physiological changes in the protist Euglena gracilis during exposure to heavy metals of heterotrophic and autotrophic cells. Comp Biochem Physiol. 1997;116:265-72.

[41] McGrath JA, Di Toro DM. Validation of the target lipid model for toxicity assessment of residual petroleum constituents : monocyclic and polycyclic aromatic hydrocarbons. Environ Toxicol Chem. $2009 ; 28: 1130-48$. 
[42] Aksmann A, Tukaj Z. The Effect of Anthracene and Phenanthrene on the Growth, Photosynthesis, and SOD Activity of the Green Alga Scenedesmus armatus Depends on the PAR Irradiance and $\mathrm{CO}_{2}$ Level. Arch Environ Contam Toxicol. 2004 ;47: 177-84.

[43] Patel JG, Nirmal Kumar JI, Khan SR. Consequences of Environmentally Hazardous Polycyclic Aromatic Hydrocarbon- Anthracene Treatment on Cyanobacteria. Int J Appl Sci Biotechnol. 2015 ; 381-6.

[44] Dugger DL, Stanton JH, Irby BN, McConnell BL, Cummings WW, Maatman RW. The Exchange of Twenty Metal Ions with the Weakly Acidic Silanol Group of Silica Gel. J Phys Chem 1964;68:757-60.

[45] Nassif N, Roux C, Coradin T, Bouvet OMM, Livage J. Bacteria quorum sensing in silica matrices. J Mater Chem. 2004;14:2264-8.

[46] Nassif N, Roux C, Rager MN, Bouvet OMM, Coradin T, Livage J. A sol-gel matrix to preserve the viability of encapsulated bacteria. J Mater Chem. 2003 ; 13:203-8.

[47] Aguado J, Arsuaga JM, Arencibia A, Lindo M, Gascon V. Aqueous heavy metals removal by adsorption on amine-functionalized mesoporous silica. J Hazard Mater. 2009;163:213-21. 
Table 1. Fluorescence inhibition (in \%) for the three microalgae in solution and within hybrid matrices for $10 \mu \mathrm{M}$ pollutant solutions

\begin{tabular}{lllllllllll}
\hline & \multicolumn{3}{c}{$\mathrm{Cd}(\mathrm{II})$} & \multicolumn{3}{c}{$\mathrm{Pb}(\mathrm{II})$} & \multicolumn{3}{c}{ Anthracene } \\
& solution & APTMS & ETES & solution & APTMS & ETES & solution & APTMS & ETES \\
A. flos-aquae & 28.5 & 0 & 24.5 & 23.5 & 0 & 22 & 27 & 24 & 0 \\
C. vulgaris & 33.5 & 0 & 31.5 & 29.5 & 0 & 26.5 & -2.5 & 0 & 0 \\
E. gracilis & 33 & 0 & 31.5 & 1.5 & 0 & 0 & 1.5 & 0 & 0 \\
\hline
\end{tabular}




\section{Figure captions}

Fig. 1 Overview of the encapsulation route

Fig. 2 Effect of $\mathrm{Cd}(\mathrm{II}), \mathrm{Pb}(\mathrm{II})$ and anthracene addition to (a,d) A. flos-aquae, (b,e) C. vulgaris and (c,f) E. gracilis suspensions as monitored by (a-c) inhibition of chlorophyll a fluorescence and (d-f) ATP-metry.

Fig. 3 Effect of pollutants on (a) A. flos-aquae,, (b) C. vulgaris and (c) E. gracilis encapsulated in a pure silica gel, (d) anthracene on cells encapsulated in APTMS-modified gels, (e,f) Cd(II) and $\mathrm{Pb}(\mathrm{II})$ addition on cells encapsulated in ETES-modified gels on chlorophyll a fluorescence intensity. All pollutants were at a $10 \mu \mathrm{M}$ concentration. Arrows indicate the time of pollutant addition.

Fig. 4 (a) $\mathrm{N}_{2}$-sorption isotherms at $77 \mathrm{~K}$ of the pure and modified silica aerogels and (b) calculated pore size distribution.

Fig. 5 (A) HPDEC-MAS ${ }^{29} \mathrm{Si}$ and (B) $\left\{{ }^{1} \mathrm{H}\right\}{ }^{-29} \mathrm{Si} \mathrm{CP}$ MAS (contact time $=3 \mathrm{~ms}$ ) NMR spectra for various aerogels

Fig. 6 2D $\left\{{ }^{1} \mathrm{H}\right\}{ }^{29}$ Si HETCOR correlation spectra (contact time $=3 \mathrm{~ms}$ ) for (a) Ludox-only, (b) ETES-silicates and (c) ETES-Ludox-silicates aerogels. Symbols indicate the proposed attribution of cross-peak signals to Si atoms originating from Ludox $(O)$, silicates $(\square)$ and ETES $(\diamond)$

Fig. 7 Schematic representation of the proposed fate of anthracene and metal ions in contact with (a) the pure silica gel, (b) the APTMS-modified gel and (c) ETES-modified gel 
Fig. 1

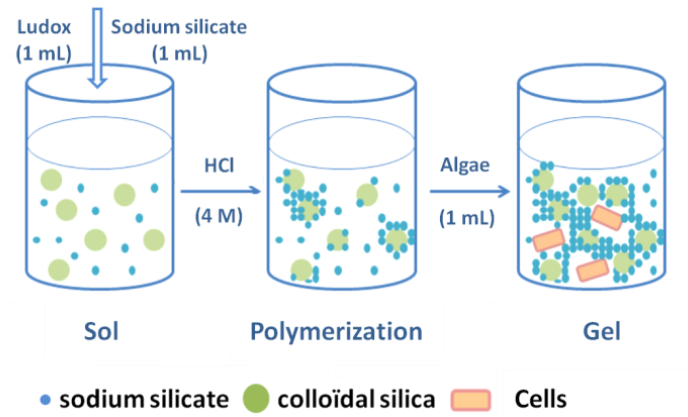


Fig. 2
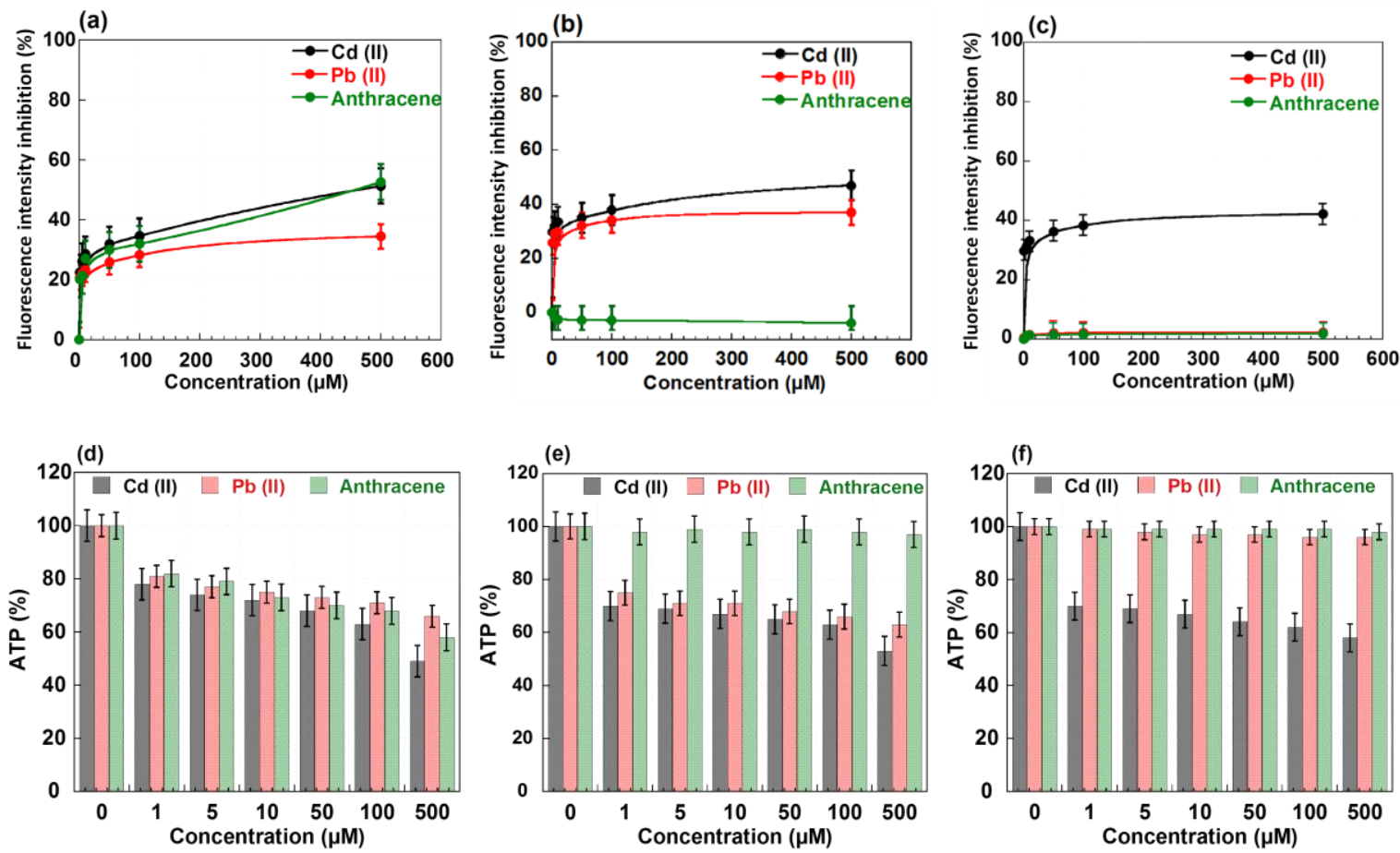
Fig.3
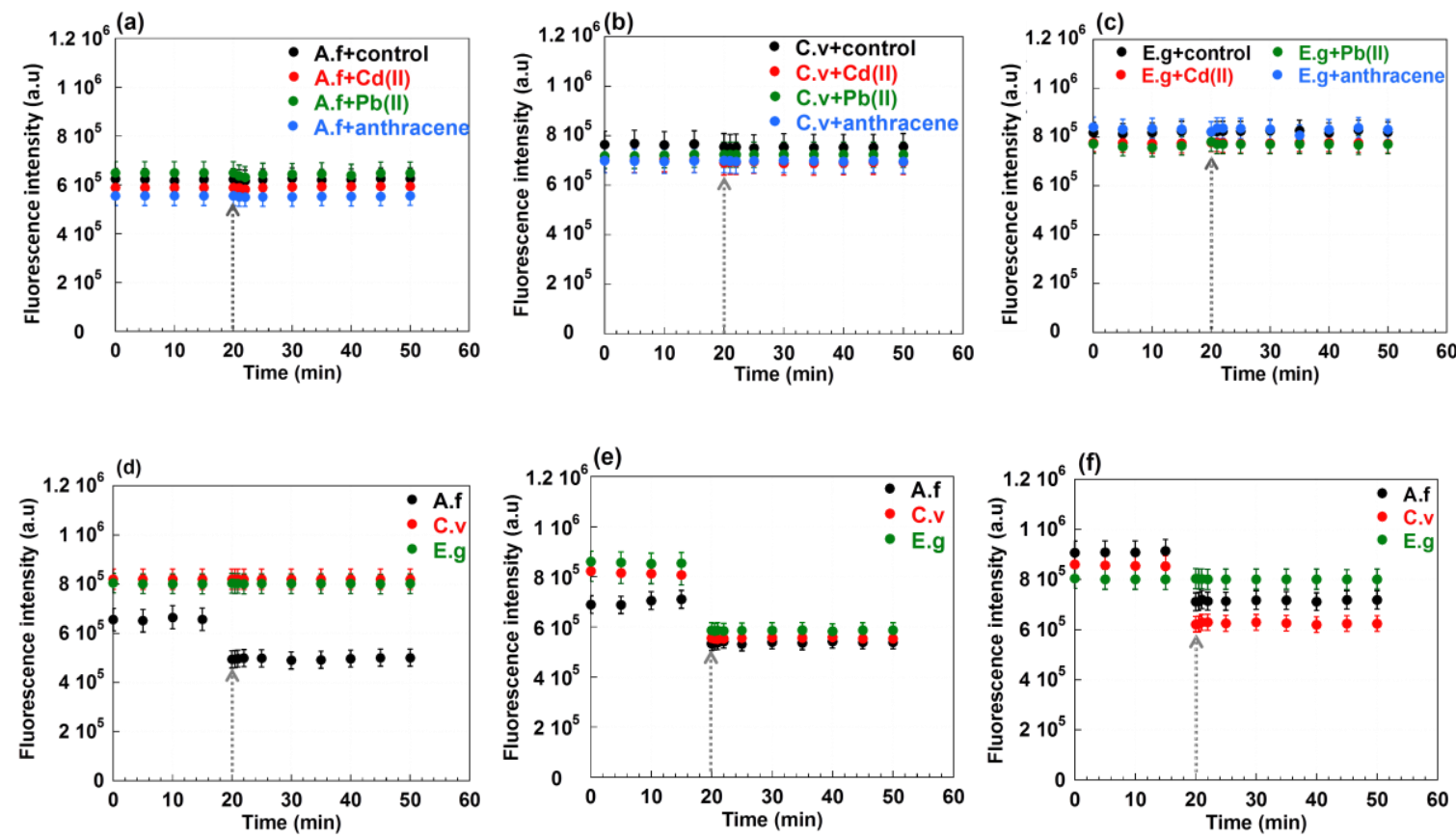
Fig. 4
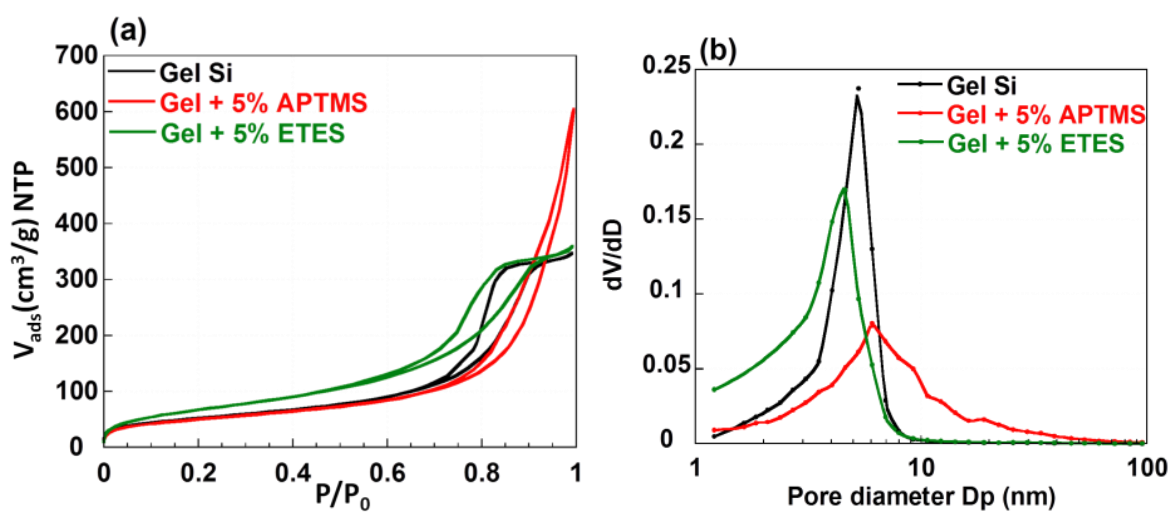
Fig. 5

(A)

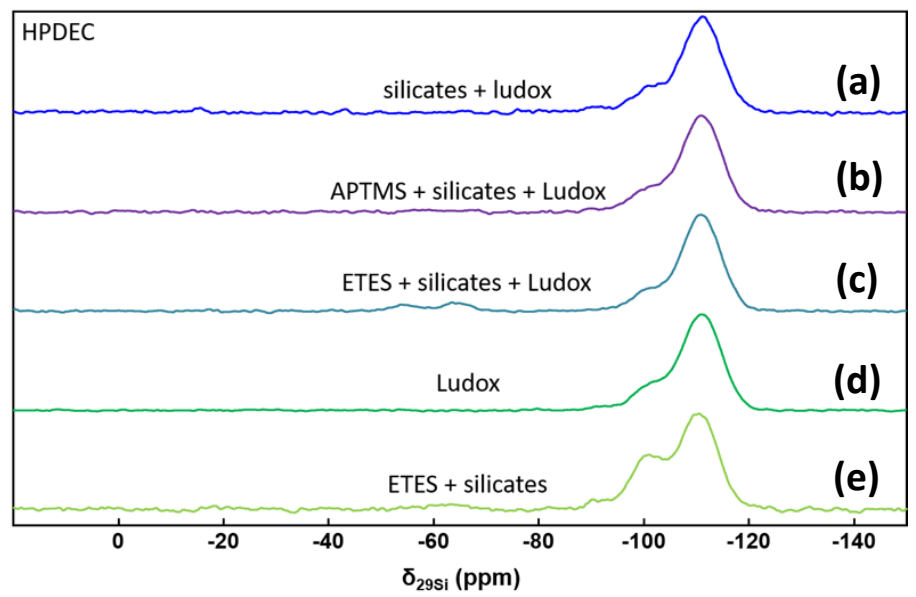

(B)

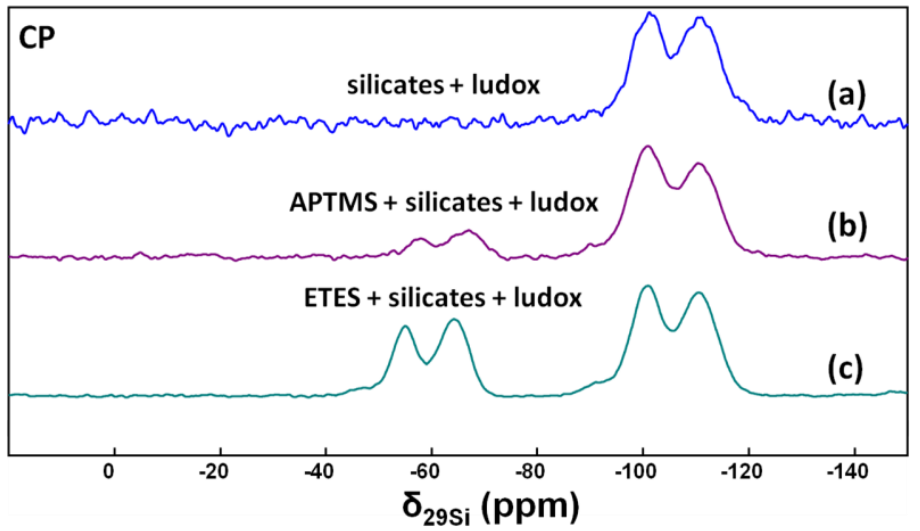


Fig. 6
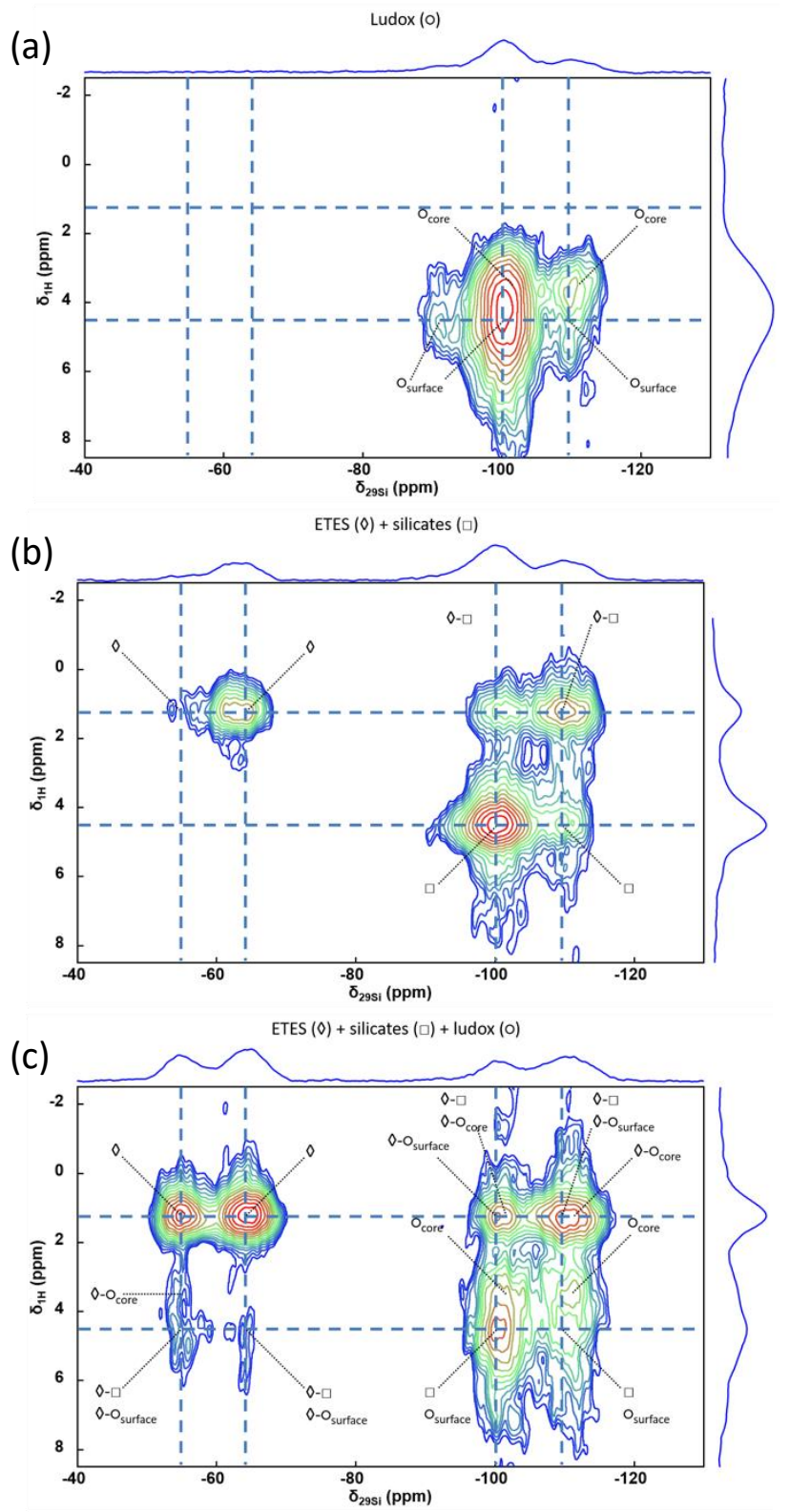
Fig. 7

(a) pure silica

(b) APTMS-silica

(c) ETES-silica
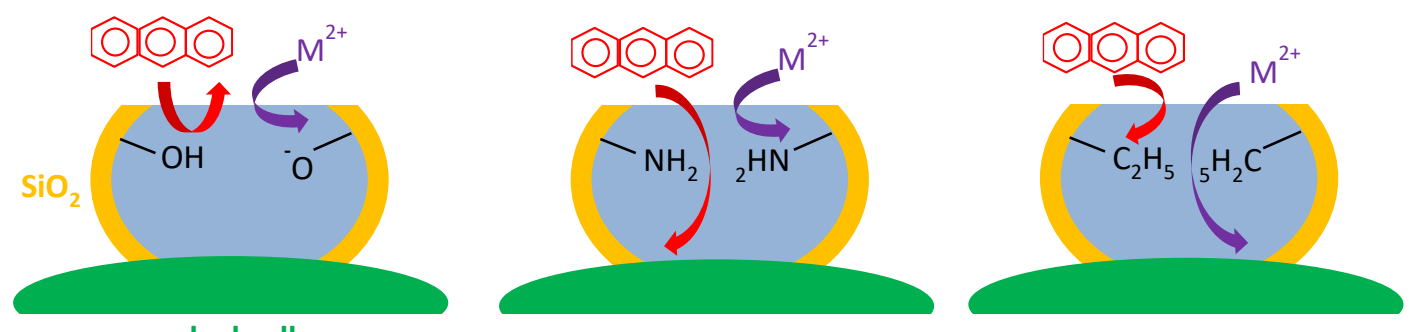

algal cell 